\title{
Dylan Thomas’s 18 Poems: The Poet’s Articulate Voice
}

\author{
S. Bharadwaj ${ }^{1^{*}}$ \\ ${ }^{1}$ Department of English, Annamalai University (Formerly), India \\ * S. Bharadwaj, E-mail: mithrabharath@yahoo.in
}

\begin{abstract}
In 18 Poems, Dylan Thomas's search for rhymes around the poles is really a quest for the significant voice of poetry. At one level, the poem articulates the poet's craving for home and the assurance that this resemblance of a home provides. But it reveals a deeper concern, a quest for and commitment to human reality; and for Thomas, reality is now identified with the paradoxical poetry of Yeats in contrast to Auden's intellectual art. Linda M. Shires holds that "what is remarkable is the originality and intensity with which" his themes such as birth and death, process and decay, are introduced. To Walford Davies, Thomas's early poetry, while offering "the reader only an impenetrable enigma" is "difficult and obscure in an individual way". John Ackerman explains that the paradoxical attitude of Thomas in 18 Poems "occasions much of the obscurity ... the images, however, are usually grouped by a sturdy advancing rhythm". In the study of Thomas's 18 Poems, the critics whose focal point is more on obscurity and musical setting hardly discuss his search for poetic image. Hence, this paper, adopting a figurative study, strives to unfold the meaning of the poet's dramatic language suggestive of the Yeatsian articulate voice that contradicts the Word-centric articulate silence of Auden.
\end{abstract}

\section{Keywords}

Hound, articulate, effeminacy, ephemeral, hieroglyphics, humility, animating

\section{Introduction}

The close of the twenties witnessed a collapse of faith in all accredited systems, and the poets of the thirties, W. H. Auden, Cecil Day Lewis, Stephen Spender and Louis MacNeice searched for a concept of a stable order as a frame of reference despite their contrary tendencies, "out of the Future into actual History” (Look Stranger!, p. 12). They "speak of” what "they know”. Day Lewis confesses:

When love's a cripple, faith a bed-time story,

Hope eats her heart out and peace walks on knives,

And suffering men cry an end to this sorry

World of whose children want alone still thrives... (Collected Poems, p. 220).

To demonstrate and confirm existing imperfection and uncertainty was, as MacNeice observes, the aim of politics, religion and philosophy and yet the poet "hankers to and touch the pantheon":

Conscious of waste of labour, conscious of spite and hate, 
Of dissention with his neighbor, of beggars at the gate,

But conscious also of love and the joy of things and the power

Of going beyond and above the limits of the lagging hour... (Collected

Poems, p. 266).

Auden's poems articulate a deepening perplexity, and the development in his thought is marked by a shift from "the language of moderation" (LS, p. 26) to "the language of learning and the language of love” (p. 52), from the vocabulary of assertion to the vocabulary of doubt and conflict though "mainspring of our striving towards perfection".

Dylan Thomas's creativity is marked as much as by a search for form as by a fresh exploration of reality. He records:

My throat knew thirst before the structure

Of skin and vein around the well

Where words and water make a mixture

Unfailing till the blood runs foul;

My heart knew love, my belly hunger;

I smelt the maggot in my stool (Poems, p. 41).

As individual distinctness was the central focus, "the private world of intuition and metaphysics was more important to the poets of the 1940s than the political and intellectual world of the 1930s. And it is easy to stereotype the period as romantic and irrational; yet part of that irrationality was absorbed into systems of belief" (Shires, pp. 34-35). Day Lewis redesigns the purpose of Thomas's 18 Poems in his own words:

This clay that binds the roots of man

And firmly foots his flying span--

Only this clay can voice, invest,

Measure and frame our mortal best (DCP, p. 183).

The failure to order his shifting reactions to a system assumes a special poignancy in Thomas's 18 Poems because of his conviction in experiential mode, “conscious of sunlight, conscious of death's inveigling touch ... not completely conscious but partly—and that is much" (MCP), because of "his profound distrust of the intellect”. While opposing the intellectual trend of Auden's poems, he searches earnestly for a system of personal salvation. "He seems to have feared the influence of intellectual upon emotional and sensory experience, and consequently is reluctant to impose too rigorous a cerebral control upon his emotional perceptions and upon his imagery” (Ackerman, p. 43).

In 18 Poems, Thomas projects the sound poetic voice, the inner reality and his own creative perplexities and his chief ancillary interest is the emphasis placed on literary ancestry. Myths and nature still continue to play their roles, but the focus is shifted to the need for assimilating the past heritage. And this recognition gives a new orientation to his early poems. The perspective of Thomas Hardy helped Thomas to dramatize his personal situation and affords the necessary nourishment; it also 
produces a sense of urgency. In 18 Poems, the poet's mind is partly abstracted under the "autumnal spells” of John Donne, and in such a state of tranced aloofness he is unable to respond fully to the reality of the situation. Thomas explains:

And from the cloudy bases of the breath

The word flowed up, translating to the heart

First characters of birth and death (Poems, p. 83).

The experience with Hardy's Poems of the Past and the Present, however, is not in any way painful compared to Donne's songs, "the heartless words ... the heart is drained ... spelling in the scurry ... of chemic blood" and "the dark-vowelled birds" (p. 53). Then, the metaphysical aesthetic of Donne forces the paradox of death-in-life as the poet's way of knowledge, and Thomas rightly notes that the vehemence of pain is undone: "My fuses timed to charge his heart ... he blew like powder to the light ... and held a little Sabbath with the sun ... he drowned his father's magics in a dream” (Poems, p. 148). Day Lewis comments on Thomas's quest for freedom through various irreconcilable forces:

From the gashed hills of desolation

Our life-blood springs to liberty,

And in the callous eyes we see

The landscape of their dissolution (DCP, p. 175).

When Thomas read W. B. Yeats's The Tower, he found many of Yeats's poetic ideals were identical to that of Hardy. Hardy's rustic character from Wessex home, "his homely Northern breast and brain ... grow up a Southern tree ... and strange-eyed constellations reign ... his stars eternally” (Collected Poems, p. 80), "the spell of inner themes and inner poetries" (p. 140) struck Thomas's imagination pointing to Yeats's poem “The Tower” in which the poet mutters:

Death and life were not

Till man made up the whole,

Made lock, stock and barrel

Out of his bitter soul,

Aye, sun and moon and star, all,

And further add to that

That, being dead, we rise,

Dream and so create

Translunar paradise (YCP).

Yeats's celebrated observation "whatever flames upon the night ... man's own resinous heart has fed" (YCP, p. 181) shows an identity of approach to Hardy's approach to life and poetry, and it may be relevant here to refer to Hardy's remarks in the poem "A Reverie" that influenced Thomas much recounting his enforced skeptical mind hounding for free energy, free play and free voice:

"Let one be born and throned whose mould shall constitute

The norm of every royal-reckoned attribute”, 
No mortal knew or heard.

But in due days the purposed Life outshone-

Serene, sagacious, free;

--Her waxing seasons bloomed with deeds well done,

And the world's heart was won... (HCP, p. 75).

Thomas having these axioms in mind could accept Hardy's lyrical voice as Donne's formulations were not quite precise and unambiguous, "how deep the waking in the worlded clouds".

Yeats's generosity combined with keen sensibility helped Thomas to release his creative energy and finally to get over Hardy’s mannerisms through continual experimentation. Thomas admits:

The force that drives the water through the rocks

Drives my red blood; that dries the mouthing streams

Turns mine to wax.

And I am dumb to mouth unto my veins

How at the mountain spring the same mouth sucks (Poems, p. 127).

However perverse Hardy's own poetic practice may have been, he was undoubtedly a tireless experimenter, and he was able to instill into his young disciple what he needed most at that time - enthusiasm and a sense of mission. Thomas acknowledges Hardy as his introducer and it was his stimulating encouragement that spurred him to renewed creative endeavour. He was profoundly moved at the meditative lyrics of Yeats's The Tower and emulated Yeats as his poetic image. He speaks in the poem "Especially When the October Wind":

Some let me make you of the vowelled beeches,

Some of the oaken voices, from the roots

Of many a thorny shire tell you notes,

Some let me make you of the water's speeches (Poems).

In response to Yeats's dramatic poetry, Thomas exults over the "vision ... of new man strength", over the force of "manhood":

I dreamed my genesis in sweat of death, fallen

Twice in the feeding sea, grown

Stale of Adam's brine until, vision

Of new man strength, I seek the sun (Poems, p. 66).

That Thomas quickly outgrew his influence is an indirect tribute to Hardy. It is indeed a common phenomenon in the lives of all great men and creative artists that they outstrip their preceptors whom they once happened to emulate and adore; but their later maturity does not cancel their debt to their former teachers.

What 18 Poems suggests is human cultivation, human predicament, and human reality while questing for a system of individual myth as a substitute for collective mythology and intellectualism according to Vernon Watkins:

Published by SCHOLINK INC. 
Lovers speak of Venus, and the white doves,

Jubilant, the white girl, myth's whiteness, Jove's,

Of Leda, the swan, whitest of his loves.

Lust imagines him, web-footed Jupiter, great dawn

Of thundering light... (Modern Verse, p. 367).

Day Lewis, stressing the relevance of "the myth of the individual" as the poets's vehicle in the post-war poetry, writes:

Emerging from the collective mind and illuminating it during the centuries when there was no other light, their task nevertheless was to get man on his own feet, teach him to walk by himself, think and feel for himself, no longer one unit in a living aggregate but an individual human being. So the poetic myths are dead and the poetic image which is the myth of the individual, reigns in their stead (Poetic Image, p. 32).

\section{Reviews, Methods and Objectives}

Auden who has been proud of his art songs tells that in Thomas's early poems influenced by the skeptical poets Hardy and Yeats "there is no music or movement which secures ... escape from the weekday time” (MCP, p. 79). In Look Stranger! Auden, explaining Thomas's search for articulate energy in 18 Poems, comments:

Starving through the leafless wood

Trolls run scolding for their food;

And the nightingale is dumb,

And the angel will not come (LS).

To Auden, 18 Poems is informed of personal regeneration, "yours is the only name expressive there", but no one but myself is loved in these" (LS). 18 Poems, however, sees the end of Eliotian intellectual modernism, Ancient "Time” and the beginning of Yeatsian archetype, “Ancient Mind". Thomas explains:

When the galactic sea was sucked

And all the dry seabed unlocked,

I sent my creature scouting on the globe,

The globe itself of hair and bone

That, sewn to me by nerve and brain,

Had stringed my flask of matter to his rib (Poems).

Edwin Muir commends on the influence of Yeats on the young Thomas:

His little kingdom at his feet

Through which the silver rivulets flow,

For while his hoofs in silence beat

Beside him Eden and Canaan go ( $M V$, p. 360). 
In the poem "The Turning of the Leaves”, Watkins holds that Thomas's Yeatsian impersonality strikes a contrast to Auden's Eliotian impersonality:

See how it hangs in the air.

The leaves are turning now. We cannot hear

The death and birth of life. But that disguise,

Look up now, softly... (MV, p. 366).

The Apocalyptics, in contempt for logic and traditional form, advocated "semi-automatic writing" based on subjective and romantic impulses "and an associative process of creation ... to support an increasing distrust in the failures of the rational, socio-political mind ...” (Linda, pp. 28-29). Thomas in "some of his early poetry is overtly self-conscious and wildly rhetorical, much of what seems drunkenly abandoned is really very structured" (p. 45). What is significant is the "originality and intensity with which" his themes such as birth and death, process and decay, sex and redemption, are introduced. John Ackerman in his study of Thomas's poetry states that "the early poems are the product of a young, obsessed mind and have a unity of theme, technique, and attitude" (p. 38). "Difficulty occurs when the density of image embodies a depth and subtlety of emotional and sensory perception that the mind, in conceptual terms, cannot follow” (p. 43). To Walford Davies, Thomas's early poetry, while offering "the reader only an impenetrable enigma" is "difficult and obscure in an individual way" (p. 26). Ackerman explains that the paradoxical attitude of Thomas in 18 Poems "occasions much of the obscurity ... the images, however, are usually grouped by a sturdy advancing rhythm and an elaborate sound structure- - that is the imposed formal control” (p. 55). Spender estimates that Thomas "is a master of language who in his earlier poems at times let language master him. He writes in an extremely rhetorical style with a pleasure in the sound and colour of words which is intoxicating” (p. 45). In the study of Thomas's 18 Poems, the critics whose focal point is more on obscurity and musical setting hardly discuss his relentless search for poetic image. Hence, this paper, adopting a figurative study, strives to unfold the meaning of the poet's dramatic language suggestive of the Yeatsian articulate voice that contradicts the Word-centric articulate silence of Auden.

\section{Analysis and Discussion}

Yeats's The Tower opened up before the young poet Thomas the vast idea of poetry, its noble past and its unknown possibilities. How and how far could these possibilities be realized? The breathless discovery and his own consummate rendering of the experience gave him the necessary confidence, and what he needed now was a close association with poets and artists who would share his vision and join him in a common pursuit. It was indeed a happy coincidence that at this critical juncture Thomas was introduced to Auden's Poems which reiterates the idea of vast expanse. His impression was that there is a certain discrepancy between the emotional content of the poem and its ostensible cause. The discovery of Auden's historic sense leads Thomas to the far more significant vision of the whole area of poetry stretching mysteriously before and beyond his baffled stare. Auden's Poems (1928) and Poems 
(1930) "move like two ghosts before the eye", listening to the metaphysical tone of Walter de la Mare and T. S. Eliot. Thomas explains the resultant experience:

In the beginning was the three-pointed star,

One smile of light across the empty face,

One bough of bone across the rooting air,

The substance forked that marrowed the first sun,

And, burning ciphers on the round of space,

Heaven and hell mixed as they spun (Poems).

The vision is both inspiring and disturbing, and the last line gathers up the explorer's exultation, puzzlement, wonder, and awe. Myths, nature, science, and history contribute their share to the experience, but the initial impulse comes from a literary work. And it is interesting to note that Auden's first significant achievement is a poem on a poem, his Poems on Eliot's The Waste Land and de la Mare's Come Hither!; de la Mare and Eliot are, in a sense, superhuman "founders” of art song-Auden creates for them a majestic, immortal world to which they seem to belong properly. Auden sets the tone of lofty rhetoric, "we honour founders of these starving cities ... whose honour is the image of sorrow" (LS, p. 22).

The other poem "My World is a Pyramid" celebrating Thomas's association with Auden and the Auden-circle is a poor performance, a piling up of stale ideas and phrases conveying no genuine sensibility: “my Egypt’s armour”, “a starry bone”, “a blood parhelion”, “my world is cypress, and an English valley", "red in an Austrian volley”, "a hill of bones” (Poems, p. 98), "my grave is watered by the crossing Jordan ... the Arctic scut, and basin of the South", "the Atlantic corn”, "my angel's hood" (p. 99). At Oxford Day Lewis, Spender, and MacNeice remembered Auden for two things: his triumphant defence of impersonal art, and his association with the French Symbolism, particularly with Eliot. The huge canvases of his Poems have a historical significance, and in his own days he was a figure of considerable stature, receiving showers of praise, adulation, and abuse from different directions. Spender and MacNeice wrote poems paying personal tributes to him, and Day Lewis considered him fit to be numbered in future, "the swing of milk was tufted in the pap". The enthusiasm is much better conveyed in Thomas's lines:

$$
\begin{aligned}
& \text { What colour is glory? death's feather? Tremble } \\
& \text { The halves that pierce the pin's point in the air, } \\
& \text { And prick the thumb-stained heaven through the thimble, } \\
& \text { The ghost is dumb that stammered in the straw, } \\
& \text { The ghost that hatched his havoc as he flew } \\
& \text { Blinds their cloud-tracking eye (Poems). }
\end{aligned}
$$

Thomas should view Auden with reverential awe. Auden's grandiosity and flamboyance had, however, a touch of the comic, and as a person he was often haughty and also not above meanness and selfishness. This aspect of his character that lost him many of his friends and patrons Thomas could Published by SCHOLINK INC. 
recognize only later and then their mutual relation became increasingly strained; even his great poetry was listed by Thomas as "My world is pyramid. The padded mummer ... weeps on the desert ochre and the salt ... incising summer” (Poems). But in the exciting days of the early thirties this megalomaniac "lined ... with famous portraits of our ancestors ... what if those things the greatest of mankind ... consider most to magnify, or to bless” (YCP, p. 169) appeared to the young poet as a mighty figure seeking to recapture the elegant style in art.

Thomas's poem "Before I Knocked” explains a doubt, however momentarily, in regard to the functional significance of Auden's early poetry, and mentions hesitantly an alternative choice. However, Thomas while sounding his note of discordance, voices his harmonization with the experiential art of Yeats:

And time cast forth my mortal creature

To drift or drown upon the seas

Acquainted with the salt adventure

Of tides that never touch the shores.

I who was rich was made the richer

By sipping at the vine of days (Poems).

The self-laceration of the poem reveals the poet's painful sense of inadequacy, and brings back the old tension between Donne and Hardy as recorded in the poem "When Once the Twilight Locks No Longer". The poem "Before I Knocked" is not, however, a mere restatement of the earlier questioning. The inner debate takes on a different key; doubt and the feeling of spiritual vacuity here gives place to a genuine humility indicating a maturer response. The humility of Yeats involving searching self-examination also revitalizes the inner reserve of strength. He says that his poetic journey would successively take him through the realm of Flora and Pan and the realm of the human heart with its strifes and agonies to interpret the meaning of suffering in human life.

Thomas sought inspiration from different masters in different periods of his life, and this is particularly true of the formative phase. Hardy's tutelage was replaced by Yeats's, but Auden too could claim a share in the young poet's devotion; and the two contrary influences of Auden and Yeats largely shaped his poetic ideal and manner in the longer poems of 18 Poems. However radical Yeats's political ideas may have been in his early poetry, his later poetry leaves the impression of a queer admixture of energy and effeminacy. Thomas admits: "I blow the stammel feather in the vein/The loin is glory in a working pallor” (Poems). Auden's influence was salutary in one specific respect. His vision of greatness may have been a delusion, "my clay unsuckled and my salt unborn ... the secret child ..." but he helped Thomas considerably to rid himself of tawdry sentimentality and discover a new reserve of power and a new idiom, "I learnt the verbs of will, and had my secret ... the code of night tapped on my tongue ... what had been one was many sounding minded” (Poems).

The final assessment is that the archetypal world of Yeats and his focus on man's rule and energy in the process of creation appeals to Thomas more. Thomas suggests:

Published by SCHOLINK INC. 
In the beginning was the pale signature,

Three-syllabled and starry as the smile,

And after came the imprints on the water,

Stamp of the minted face upon the moon;

The blood that touched the crosstree and the grail

Touched the first cloud and left a sign (Poems).

Apart from the economy and condensation of language which it exhibits, the poem "The Tower" has been praised for its formal perfection. The magic spell and evocative power of Yeats's language and his concern with man's ultimate destiny chiefly engrossed Thomas. Thomas's search for rhymes around the poles is thus really a quest for significant vision or the significant voice of poetry, not for something merely adventitious. At one level, 18 Poems undoubtedly expresses the poet's craving for home and the assurance that this resemblance of a home provides. But the poem reveals, below the level of primary meaning, a deeper concern, a quest for and commitment to human reality; and for Thomas, reality is now identified with the paradoxical poetry of Yeats whose "articulate speech" lies in "that art ... of minding one's own business ... magnanimously” (DCP, p. 23).

Thomas's poem "Where once the Waters of Your Face” records his immediate reaction to Yeats's warmth and moral disinterestedness in moving accents. The idea of friendship and love through the antithesis of winter-spring, death-life as the inspirational source of poetry is emphasized against the outward desolation. Thomas sings of the archetypal image of the poet:

Where once your green knots sank their splice

Into the tided cord, there goes

The green unraveller,

His scissors oiled, his knife hung loose

To cut the channels at their source

And lay the wet fruits low (Poems, p. 151).

In the poem "Nineteen Hundred and Nineteen", Yeats's mind, filled with thoughts of friendship, youthful love, and poetry, triumphs over outward emptiness:

Many ingenious lovely things are gone

That seemed sheer miracle to the multitude,

Protected from the circle of the moon

That pitches common things about. There stood

Amid the ornamental bronze and stone

An ancient image made of olive wood... (p. 175).

It is significant that nature is no longer represented as a mediatory agency, and inspiration is sought in friendship, love, and the poerty of the past.

The five poems "If I Were Tickled by the Rub of Love", "Our Eunuch Dreams", "When Like a Running Grave”, "From Love’s First Fever to Her Plague”, and "All all and all the Dry Worlds Lever” 
vary in quality, but they are all extensions of or variations on the same motif. In "If I Were Tickled by the Rub of Love", Thomas describes Yeats as the most disinterested poet, "Man be my metaphor" (Poems, p. 77), he had ever known compared to Auden's transcendentalism, "death's feather on the nerve" and "the thistle in the kiss", "my Jack of Christ born thorny on the tree”. Auden seems to mediate between the two spheres, the human and the divine, but he holds a subordinate position to the poet. It is significant that Yeats as a mediator supplants nature with a human figure. The idea of mediation is also the theme of Yeats's poem "Meditations in Time of Civil War" in which the Elysium of poets and the Elysium of heroes, "the sound of the rain or the sound ... of every wind that blows" $(Y C P)$, are interchangeable although an oscillation between contemplation and action may also be discerned. Yeats has to "take our greatness with our violence":

My house

An ancient bridge, and a more ancient tower,

A farmhouse that is heltered by its wall,

An acre of stony ground,

Where the symbolic rose can break in flower,

Old ragged elms, old thorns innumerable... (p. 170).

Yeats's later poem The Tower is an affirmative dedication to poetry- "take our greatness with our bitterness"-and serves as a link between earth and heaven achieving a harmony that is a reflection of moral disinterestedness. Yeats explains:

Life overflows without ambitious pains;

And rains down life until the basin spills,

And mounts more dizzy high the more it rains

As though to choose whatever shape it wills

And never stoop to a mechanical

Or servile shape, at others' beck and call (YCP).

The poem “Our Eunuch Dreams" reveals Thomas's attitude to institutional religion and his growing agnosticism; but what is equally if not more important is that it expresses the hope that religion would be finally superseded by poetry which alone provides, in Thomas's view, the most satisfying means of humanity's salvation:

For we shall be a shouter like the cock,

Blowing the old dead back; our shots shall smack

The image from the plates;

And we shall be fit fellows for a life,

And who remains shall flower as they love,

Praise to our faring hearts (Poems, pp. 110-111).

Thomas's faith in the poetry that ends on a prophetic note is identical to Yeats's "mummy truths" of religion "in the world's despite" and of communion with great souls of Elysium "where the damned 
have howled away their hearts ... where the blessed dance" as "no living man can drink from the whole wine" the staying value of life, "the fume of muscatel ... can give his sharpened palate ecstasy". He insists on the need of poetry as a substitute for religion:

Such thought, that in it bound

I need no other thing,

Wound in mind's wandering

As mummies in the mummy-cloth are wound (p. 196).

Hardy also affirms the positive value of poetry in the poem "On a Fine Morning”:

Whence comes Solace?-Not from seeing

What is doing, suffering, being,

Nor from heeding Time's monitions;

But in cleaving to the Dream,

And in gazing at the gleam

Whereby gray things golden seem (p. 114).

18 Poems, thus, anticipates Thomas's vision of poetic culture and of the poet's ruling energy as articulated in the later poem Deaths and Entrances.

Thomas's poem "When, like a Running Grave” is a restatement of earlier escapist moods, and the arena of Auden's Poems (1930) is widened to include the Eliotian concept of poetry: "what happens is continual surrender of himself as he is at the moment to something which is more invaluable. The progress of an artist is continual self-sacrifice, a continual extinction of personality” (Eliot, pp. 52-53). Auden's mysterious beauty and majesty of the regional consciousness in conformity with the European consciousness is quite a satisfying experience, but his contemporaries also feel a craving for aesthetic orientation, "that time’s jacket or the coat of ice”, "Cadaver's country in my force”, "hero skull, Cadaver in the hangar", "the cancer's fashion, or the summer feather ... lit on the cuddled tree ... the cross of fever", "the waxlights in your tower dome”, "the knock of dust, Cadaver's shoot ... of bud of Adam through his boxy shift" and "Love's twilit nation and the skull of state” (Poems, p. 149). Thomas reflects:
All, men my madmen, the unwholesome wind
With whistler's cough contages, time on track
Shapes in a cinder death; love for his trick,
Happy Cadaver's hunger as you take
The kissproof world (p. 150).

The two spheres - the ideal realm of poetry, and this mundane existence-are separated in space and set in opposition; their interrelatedness is yet to be revealed to Day Lewis, Spender, and MacNeice. The cryptic comments that Thomas makes about Auden's amoral disinterestedness "the cemented skin ... the actions' end" as Word-centric and "like a running grave", "a scythe of hairs", "a turtle in a hearse ... hauled to the dome”, "Cadaver's trap”, "his footed tape ... the bone inch”, and "heart of Cadaver's Published by SCHOLINK INC. 
candle” are different from Yeats's "truth”. Yeats distinguishes the moral disinterestedness from the aesthetic disinterestedness:

Out of a medium's mouth.

Out of nothing it came,

Out of the forest loam,

Out of dark night where lay

The crowns of Nineveh (p. 182).

The poem "From Love's First Fever to Her Plague" that Thomas composed in friendly contest with Auden renders more effectively the supremacy and significance of poetry. It anticipates in certain respects the last poem In the Country Sleep, and celebrates the natural music of earth in varied contexts. The music is heard in two different seasons; but Thomas reminds the readers of the fact in 18 Poems that the movement of seasons is cyclic, and this affirmation of process, of continuity, gives the varying songs unity and wholeness. The summer songs of Donne and Auden and the winter songs of Hardy and Yeats, the seeming contraries being gathered up and resolved in the concluding lines:

One wound, one mind, spewed out the matter,

One breast gave suck the fever's issue;

From the divorcing sky I learnt the double,

The two-framed globe that spun into a score;

A million minds gave suck to such a bud

As forks my eye;

Youth did condense; the tears of spring

Dissolved in summer and the hundred seasons;

One sun, one manna, warmed and fed (Poems, pp. 58-59).

The individuality of Auden is retained and he is placed in a familiar setting as he "transcends" the "ripening rule" with the "ancient rote-restricted ways", as he knows not "what disturbs our blood ... but its longing for the tomb”; but Hardy and Yeats are given the role of the earthly poets representing in their lyrics the principle of harmony working through the varied manifestations of nature. Throughout the poems of Hardy and Yeats is emphasized the ceaselessness of this poetry the resonance of which fills empty spaces and affords an assurance when the assurance is most needed.

The descriptive poem "All all and all the Dry Worlds Lever" gathers up the different sources of poetic inspiration enumerated in the early poems: nature, woman's beauty, mythologized nature, and ancient nature-inspired poetry. It may be argued that a reader approaching the poem with no preoccupations would be able to perceive its unity of tone and the relevance of the parts in the total design:

How now my flesh, my naked fellow,

Dug of the sea, the glanded morrow,

Worm in the scalp, the staked and fallow.

All all and all, the corpse's lover, 
Skinny as sin, the foaming marrow,

All of the flesh, the dry worlds lever (Poems).

It is true that the poet did not start 18 Poems with a clear sense of direction, that the central conception evolves through successive stages of composition. And that the vision remains partly inchoate. However, a pattern of meaning emerges. 18 Poems in its final form explores the origin, nature, and function of poetry, and also the relationship between poetry, nature, and human life, between Donne and Hardy, Auden and Yeats:

In 18 Poems, Thomas envisages a journey of the mind through successive phases, and these phases are, (1) apprehension of the sensuous beauty of nature (feminine charm being part of this beauty), (2) perception of the principle of harmony working in nature and, (3) finally, the convergence of the immortal-mortal towards a point of coalescence in which the mind is liberated from the mutable world and enjoys inclusive structure which is a repetition on the creative plane of happiness enjoyed on earth. Thomas sums up in the poem "In the Beginning":

In the beginning was the secret brain.

The brain was celled and soldered in the thought

Before the pitch was forking to a sun;

Before the veins were shaking in their sieve

Blood shot and scattered to the winds of light

The ribbed original of love (Poems).

Yeats's early vision of poetry is that the human poet realizes fully his creative urge only when he completely ascends from earthly to structural beauty, "I pace upon the battlements and stare ... on the foundations of a house, or where ... Tree, like a sooty finger, starts from the earth (YCP, p. 164) ... There is an added implication that poetry is the articulate voice of the immortal poets although this voice has to be rendered in human speech.

Thomas affirms a necessary connexion between human world and creative imagination and justifies the poetic vocation as the highest human pursuit. The ameliorating function of poetry is also implied towards the end of 18 Poems. He concludes:

Flower, flower the people's fusion,

O light in zenith, the coupled bud,

And the flame in the flesh's vision.

Out of the sea, the drive of oil,

Socket and grave, the brassy blood,

Flower, flower, all all and all (Poems).

The poet's role, according to Yeats, is to inspire the fellow-poets and to illuminate the human world. The Tower, exemplifying Yeats's dramatic imagination, expresses his faith in moral disinterestedness:

Old lecher with a love on every wind,

Bring up out of that deep considering mind 
All that you discovered in the grave,

For it is certain that you have

Reckoned up every unforeknown, unseeing

Plunge, lured by a softening eye,

Or by a touch or sigh,

Into the labyrinth of another's being... (p. 166).

Moreover, Yeats's vicariousness coincides with Hardy’s ideal of co-existence, “convincing triumphs over neighbour lands" where "none dubious of the cause, none murmuring” but "wives, sisters, parents, wave white hands and smile ... as if they knew not that they weep the while” (HCP, p. 75). Yeats as a poet of "hearts and heads" knows that the benchmark of poetry and poetic character is "all that lamentation of the leaves ... could but compose man's image and his cry" (YCP, p. 32 ), "the greatness of the world in tears", "a climbing moon upon an empty sky", "the instant clamorous eaves" (YCP) rather than "all the heavenly glory" "self-born mockers of man's enterprise" (p. 184), "befitting emblems of adversity" (YCP), "all that famous harmony of leaves" that "had blotted out man's image and his cry".

The focus is shifted in the first poem "I See the Boys of Summer" to the artistic tradition created and established by the great masters, Yeats, Eliot, Auden and Thomas. It is concerned with issues that have more immediate bearing on the future of Auden's contemporaries, Day Lewis, Spender, and MacNeice. The genuine heritage is sifted from the spurious, and the questions that disturb Auden are: how far he is worthy of the Eliotian inheritance and to what extent he can add significantly to past achievement. Thomas recasts:

\author{
But seasons must be challenged or they totter \\ Into a chiming quarter \\ There, punctual as death, we ring the stars; \\ There, in his night, the black-tongued bells \\ The sleepy man of winter pulls, \\ Nor blows back moon-and-midnight as she blows (Poems, p. 71).
}

Poetry the passive and active, although the division is not so simple and sharp, points to a higher reality but this gradation does not nullify the value of contemplative repose: it is more gentle, more soothing, more tranquil, more healthful, more serene and more full of visions than his romantic and sad contemporaries. The feeling of religious awe implies dedication to a pursuit that is not distracted by pragmatic considerations.

The vast idea of poetry rolls before Thomas; and he seeks to clarify his own intentions to be realized in successive stages, and at a broader level, to examine the nature and function of poetry itself against the background of the defeated poets of the thirties. Thomas persuades the grievous poets to rise and labour for personal greatness:

In spring we cross our foreheads with the holly, 
Heigh ho the blood and berry,

And nail the merry squires to the trees;

Here love's damp muscle dries and dies,

Here break a kiss in no love's quarry.

O see the poles of promise in the boys (p. 72).

18 Poems, as it discusses the divided attitude of Auden's contemporaries, does not present a unified vision. It has three different ideals of poetry corresponding to the mental oscillations of Auden's contemporaries, Thomas, and Auden.

At one end, there is what may be called the escapist ideal consonant with the realm of Flora and old Pan and associated with the reverie of Day Lewis, Spender, and MacNeice. The kind of poetry orientated to this ideal has its bearing on human life in so far as it eschews pain and turns the mind to pleasing song: "there in the sun the frigid threads ... of doubt and dark they feed their nerves", "there in the deep with quartered shades ... of sun and moon they paint their dams", "there from their hearts the dogdayed pulse ... of love and light bursts in their throats" (Poems). The second conception has a direct human significance, and the aim is to grasp and interpret the complex fabric of existence, the chief emphasis being on the reality of suffering and the poems of Yeats and Thomas. "there in their heat the winter floods ... of frozen loves they fetch their girls", "there, in his night, the black-tongued bells ... the sleepy man of winter pulls” (Poems). The third ideal representing Auden's transcendental: poetry is conceived as rising above the plane of sordid existence and reaching towards the sea of ultimate verities, "the gold tithings barren”, "the cargoed apples in their tides", "these boys of light are curdlers in their folly", "the bright-eyed worm on Davy's lamp" (Poems).

The three ideals are not clearly defined or categorized. The outlines are often blurred, and much of the incoherence of 18 Poems arises out of this conceptual imprecision. There is no dominant symbol, and the uncertainties are not held together in a coherent structure; thoughts and images move in quick succession conducting the reader along a kaleidoscopic sequence. Auden displays these comments in the "Prologue" to Look Stranger!:

Make simpler daily the beating of man's heart; within,

There in the ring where name and image meet,

Inspire them with such a longing as will make his thought

Alive like patterns a murmuration of starlings

Rising joy over wolds unwittingly weave... (p. 11).

Day Lewis, however, discovers a structural coherence in the apparently unconnected thoughts and shows how hopes of poetry alternate with doubt and reassurance:

Pausing between shifts or in the pub at evening

We feel their generous heat;

We remember them as the glowing fruit remembers

Sap-flow and sunshine (p. 157). 
Spender's The Still Centre helps the readers considerably in understanding 18 Poems and in tracing a pattern of thought. The eddies and currents, turns and counterturns reflecting an unquiet, restless, searching mind in Thomas's thought, however, are more sinuous than Day Lewis's neat formulation. He describes the hound of human voice:

Flesh, bone, muscle and eyes

Assembled in a tower of lies

Were scattered on a icy breeze (Spender, p. 59).

MacNeice defines the tautology involving the poetic tradition of Hardy, Yeats, and Thomas in a plain speaking manner:

Which when caught between the beginning and end

Turn other than themselves, their entities unfurled,

Flapping and overlapping — a tree becomes

A talking tower, and a woman becomes world (MCP, pp. 209-210).

Thomas's initial stupefaction is followed by a sense of participation in the universal orchestration of Yeats, and he assigns to himself the function of an earthly medium communicating the voice of poetry. "And the fire flames with a bubbling sound for world/Is more spiteful and gay than one supposes/On the tongue on the eyes on the ears in the palms of one's hands ...” (p. 86). Thomas considers himself till now only a passive vehicle, but the thought of his own individual role is also simultaneously present.

Auden's contemporaries perceive that it is the primary affection that constitutes the animating principle of Thomas's 18 Poems and what they note especially in Auden is a withering of sensibility. Thomas underlines:

We are the dark deniers, let us summon

Death from a summer woman

A muscling life from lovers in their cramp,

From the fair dead who flush the sea

The bright-eyed worm on Davy's lamp,

And from the planted womb the man of straw (Poems).

This is the first time that they recognize the need to present life in its totality, to render multiple experience. "All is above board, order is restored/Time on horseback under a Roman arch" (MCP, p. 85). Their triumphant affirmation in Thomas is followed by a sudden doubt that the aspiration may not be realized. Auden's transcendence is indeed a debasement of the humanitarian ideal, but this aestheticism marks a distinct phase in Auden's journey. MacNeice deplores the shrinkage in the range of experience in Auden's poetry:

The room was suddenly rich and the great bay-window was

Spawning snow and pink roses against it

Soundlessly collateral and incompatible... (MCP). 
So, it is not Auden's hush of natural landscape reasserting the Eliotian noble heritage of logocentric metaphysical tradition and the paradox of death-in-living, the "death's glory" of the older poets, but the graphocentric Yeatsian eloquence, "through winter-time we call on spring ... and through the spring on summer call ... and when abounding hedges ring ... declare winter's best of all (YCP, p. 179), the undying voice of Hardy's poetic tradition, "that listless effort tends ... to grow percipient with advance of days ... and with percipience mends” (HCP, p. 168) whispered in the breathless quietness of Thomas's 18 Poems that inspired Auden's contemporaries with a zeal for emulation, "the signal moon is zero in their voids", "O see the pulse of summer in the ice”. Thomas voices their hope for life and love, poetry of freedom:

I see you boys of summer in your ruin.

Man in his maggot's barren.

And boys are full and foreign in the pouch.

I am the man your father was.

We are the sons of flint and pitch.

O see the poles are kissing as they cross (Poems).

Thomas's first volume 18 Poems that portrays the wedge between Auden and his friends enacts a dramatic conflict between the metaphysical, intellectual tone of Donne and Auden and the archetypal, articulate voice of Hardy and Yeats.

\section{Findings and Interpretations}

Auden's early poetry conveys adequately a mood of breathless excitement and expectancy, and offers glimpses through the effective use of certain key-symbols of the mysterious visions to which natural beauty and sensory perceptions may lead. In Poems, he commands:

We know it, we know that love

Needs more than the admiring excitement of union,

More than the abrupt self-confident farewell,

The heel on the finishing blade of grass,

The self-confidence of the falling root,

Needs death, death of the grain, our death,

Death of the old gang... (Poems).

Auden celebrates the Eliotian commandment, "poetry is not a turning loose of emotion, but an escape from emotion; it is not an expression of personality, but an escape from personality” (Eliot, p. 58), which has at one level a specific historical relevance indicating the direction of the contemporary literary movement. The passage, as Thomas demonstrates, also throws light on an important aspect of the early Audenesque aesthetic:

Man of my flesh, the jawbone riven,

Know now the flesh's lock and vice, 
And the cage for the scythe-eyed raven.

Know, O my bone, the jointed lever,

Fear not the screws that turn the voice,

And the face to the driven lover (Poems).

The aesthetic implied in both Eliot and Auden has two aspects. First, poetry incarnates, through the vehicles of word and rhythm, the rhythm or order in Nature, "all that shapes from the caul and suckle ... stroke of mechanical flesh on mine ... square in these worlds the mortal circle”. Secondly, the poet can read Nature's mysterious hieroglyphics only when he transcends the plane of finite existence and attains to the region of immortal bliss, "all all and all the dry worlds couple ... ghost with her ghost” (Poems). Thomas's moral disinterested being, on the other hand, seeks to do good to the depressed fellow-poets through non-attachment. This disinterestedness denotes the Yeatsian moral attitude directed towards a moral end: it may be tolerant of sinners, but it is relentless towards moral evil:

Light in the branches weaves.

Hard is the waiting moment while it waves,

This tree whose trunk curves upward from the stream

Where faltering ripples strum $(M V)$.

This must be distinguished from aesthetic disinterestedness of Auden, "the death and birth of life" (p. 366 ) in which both good and evil are equally interesting as concrete particulars.

What 18 Poems suggests is the mysterious effect of poetry permeating the physical world, "life's green standards they've advanced ... to the limits of your salt unyielding zone” (DCP, p. 186), and the specific nature of Auden's historic love and his art song, "one the rare air made dizzy renounced ... earth, perfect ... null, the prince and image of despair” (p. 185), has little relevance in the context. Day Lewis explains "the mounting stages of" Auden’s "oppression": "Built from their bone, I see a power-house stand/To warm men's hearts again and light the land” (p. 188). The relevance of fellow-mortals, human love as the source of poetic power that they help the poet to make the transition from the mortal condition to the bourne of immortality is emphasized. Day Lewis sings of poetic power and permanence born of the poet's labour:

The best, neither hoarding nor squandering

The radiant flesh and the receptive

Spirit, stepped on together in the rhythms of comrades who

Have found a route on earth's true reckoning based (DCP).

Auden's early poetry adjudged as "his enexampled, best creation" promotes the Word-centric architectural symbol of an intellectual soul and the self-annuling ironic, musical structure and in contradistinction Thomas's early poetry deemed as "the shape of man's necessity full grown” (DCP) projects the world-concentric archetypal image of a poet and the self-oriented lyrical, paradoxical structure. MacNeice observes: 
That your whole life till then showed an endeavour

Towards a discovery—and if pains

Were lost the loss is ours as well; for you are out of

This life and cannot start any more hares forever (p. 270).

Jacques Derrida, differentiating the "event" of post-Structuralism from the Structuralism of "structure or the structurality of structure" or "the process of giving it a centre or of referring it to a point of presence, a fixed origin”, defines:

The function of this centre was not only to orient, balance, and organize the structure-but above all to make sure that the organizing principle of the structure would limit what we might call the play of the structure. By orienting and organizing the coherence of the system, the center of a structure permits the play of its elements inside the total form. And even today the notion of a structure lacking any center represents the unthinkable itself (p. 90).

Thomas's poetic ideals of transfiguration and moral disinterestedness, while keeping the thoughts of transubstantiation and transmigration, the "monuments of unaging intellect", "singing school" and "the artifice of eternity", "the singing masters of my soul" quite aloof, are evidently Yeatsian. Yeats explains his articulate and unagitated sceptical mind searching for "monuments of its own magnificence":

Once out of nature I shall never take

My bodily form from any natural thing,

But such a form as Grecian goldsmiths make

Of hammered gold and gold enamelling

To keep a drowsy Emperor awake;

Or set upon a golden bough to sing

To lords and ladies of Byzantium

Of what is past, or passing, or to come (p. 163).

Thomas's poetic ideal is, thus, consonant with Yeats's later view of life and poetry. "Not the twilight of the gods but a precise dawn/Of sallow and grey bricks, and newsboys crying war” (MCP).

In 18 Poems without conscious deliberation, Thomas reaches towards a concept of poetry that would work into a vast design the intricate reality of the human situation; the concern with the dark mysteries of human life marks a clear departure from the Audenesque emphasis on the historic sense and musical aspects of poetry. He clinches:

We summer boys in this four-winded spinning,

Green of the seaweeds' iron,

Hold up the noisy sea and drop her birds,

Pick the world's ball of wave and froth

To choke the deserts with her tides,

And comb the county gardens for a wreath (Poems).

Thomas's 18 Poems, so, comes full circle; the accession to trance in the opening poem and the return to Published by SCHOLINK INC. 
it towards the end provide the framework for the time-conscious poets's shifting thoughts and visions of self-oriented organic structure, freedom, freeplay, free speech and immortality in 25 Poems. He "had chosen ... thus" Hardy and Yeats as his ruling energy and stirred the "fervourless" poets of the thirties, "the weakening eye of day" (HCP, p. 134) and "hurried" them "through the smooth and rough ... and through the fertile and waste ... protecting, till the danger past ... with human love" (YCP, p. 180) "to fling” their "soul ... upon the growing gloom” and "death-lament". Watkins perceives that the sound skeptical voice of Thomas rejuvenates and resurrects the grievous fellow-poets of the thirties to become creative and compose dramatic songs of their choice, “... the roots tapering tendrils eat/Parched earth away that they may be/Nearer the source those fibres must obey” ( $M V$, p. 365).

\section{Conclusion}

In 18 Poems Thomas, "imposing ... on flux an architectonic" makes "cone of marble, calyx of ice ... spandrel and buttress, iron ... loops across the void ... stepping stones in the random” (MCP, p. 181), demonstrates his vicariousness in the archetype of his joy as the "invaluable ... lyrical surprise" (p. 269) to the fallen poets of the thirties, "a spider dangling ... over chaos and man a chaos". The poems exemplify a universal truth, and the truth is both terrifying and assuring, "the death of friends, or death ... of every brilliant eye ... that made a catch in the breath ... seem but the clouds of the sky ... when the horizon fades" (YCP, p. 168). Thomas's articulate voice offers the poets of the thirties hope for poetry, freedom and freeplay past danger. The same line of thought is echoed in MacNeice's poem "The Casualty" in which he rightly notes that the vehemence of "that thread of so articulate silence" of Auden's poems "where no time presses and no days begin" is so severe that he is damned as "faded star", "half-frustrated", and that it is improbable for him "to find a more accordant friend" (p. 267) as he is "outside the cliques, unbothered with the fashion" (p. 268). MacNeice, therefore, bids Auden to be "sympathetic, warm ... towards things as well as people" $(M C P)$ to "see ... the integrity of differences.” In Look Stranger! (1936) Auden, wooing perfection, tells his contemporary poets, "lacking sense" and "articulate speech", "a sad-coloured landscape" that had not woven "world-webs to according lutes and tabors ... with nevermore this too remorseful air upon her face $\ldots$ as of angel fallen from grace" (HCP, p. 102), that "converting number from vague to certain" is to "bring joy, bring day of his returning” (LS, p. 43). And Thomas's second volume 25 Poems (1936), in turn, drums his highly articulated poetic voice, fashions "everything from nothing everyday" and admonishes the grievous poets of the thirties to "make one last integration, find a Form ... grow out of formlessness when the Atlantic hid you $(M C P) \ldots$... 


\section{References}

Ackerman, J. (1964). Dylan Thomas: His Life and Work. London: Macmillan.

Allott, K. (Ed.). (1962). Contemporary Verse 1918-60. Harmondsworth: Penguin.

Auden, W. H. (1930). Poems. London: Faber.

Collected Poems 1929-1954. (1954). London: Hogarth-Cape.

Davies, W. (2003). Dylan Thomas. New Delhi: Viva Books.

Day, L. C. (1947). The Poetic Image. London: Cape.

Derrida, J. (1972). Structure, sign and play in the Discourse of the human sciences. In L. David (Ed.), 20th Century Literary Criticism: A Reader. London: Longman.

Eliot, T. S. (1935). Tradition and the Individual Element. Sacred Wood. London: Faber.

Hardy, T. (2006). Collected Poems. Herfordshire: Wordsworth.

Look Stranger! (1936). London: Faber.

MacNeice, L. (1949). Collected Poems 1925-1948. London: Faber.

Poetry Since 1939. (1951). London: Faber.

Roberts, M. (Ed.). (1951). Modern Verse. London: Faber.

Shires, M. L. (1985). British Poetry of the Second World War. London: Macmillan.

Spender, S. (1935). The Still Centre. London: Faber.

Thomas, D. (2004). Poems. London: Hunter.

Yeats, W. B. (2004). Collected Poems. London: Wordsworth. 